\title{
An Acacia Based Design for Sustainable Livestock Carrying Capacity on Irrigated Farmlands in Semi-Arid Africa
}

\author{
Jon D. Unruh \\ University of Arizona
}

\begin{abstract}
Multiple land use designs are becoming increasingly necessary in semi-arid Africa as growing populations focus numerous production systems onto spatially limited arable lands. Engineering distinct land uses into a single area ideally requires that land use components compliment each other, and operate in predictable magnitudes. Quantitative evaluations of components to be included in multiple land use designs are necessary to determine both how components would 'fit' together, and how these would serve populations participating in distinct production systems.

With data gathered in Somalia, this study considers a design in which fodder producing trees and irrigated agriculture could be integrated. Following a discussion of the benefits of such an integration, this analysis focuses on a quantitative examination of potential livestock carrying capacity from Acacia albida trees in an irrigated area. Comparisons are made with observed livestock numbers in order to determine if such a design could accommodate the seasonal influx of nomadic herds. The land use elements that comprise carrying capacity are themselves examined to see which elements might be managed to offset or take advantage of those which are not easily managed.
\end{abstract}

\section{Introduction}

Access to high quality arable land in the tropics is an issue of growing importance as populations increase and energy limited countries attempt to utilize these areas to meet urban and export food objectives. In arid and semi-arid Africa the limited spatial extent of high potential lands has concentrated national agricultural development in these areas. However displacement of pre-existing land uses can result in pronounced social and biotic impoverishment for the populations concerned. This occurs as lower quality, easily degraded lands are then used for subsistence, and resource conservative strategies are abandoned. Vulnerabilities to local and regional problems of 
various magnitudes consequently increase.

The problems associated with development and displacement in these areas highlight the importance of multiple land use systems in which several modes of production can operate. This paper quantitatively explores such a scheme for one of the few high potential sites in Somalia, on which dissimilar production systems depend. In this design the possibility of using fodder producing trees on boundary areas within an irrigation scheme, in a zone important to nomadic pastoralists, is investigated.

Quantifying the operational aspects of the parts or elements which make up a land use component (such as fodder trees) is important because transferring such components into recipient systems requires that these function in predictable proportions under a variety of conditions. In this context the elements which influence livestock carrying capacity from Acacia albida trees are analyzed with the aim of playing off those elements that are easy to change against those that are not easy to change. The objective here is to explore the possibilities for engineering livestock carrying capacity from acacia trees on irrigated farmlands; and to evaluate the ability of these trees to 'fit' into irrigation schemes.

\section{Acacia albida and Pastoralism}

The fodder production from Acacia albida trees in widely varying environmental conditions and production systems in Africa has been documented by a number of thorough authors (Miehe 1986; Poschen 1986; Leach and Mearns 1988; Boudet and Toutain 1980; Houerou 1980a; and the references cited in these). The tree is highly valued as a fodder resource during the dry season. Both leaves and pods are consumed by all stock, however the seed pods are particularly valuable, with high protein and other nutritive merits.

The protein content of the leaves and pods allow for greater utilization of protein deficient crop residues, which otherwise would be consumed less and with less benefit to livestock (Houerou 1980a; Radwanski and Wickens 1967). This is important when considering the livestock carrying capacity of cultivated areas. The protein content of acacia and other browse species is also much higher than that of many native grasses found on the same land at the same time (Torres 1983). Studies have shown that for livestock production systems based on rangelands in arid and semi-arid regions, dietary protein is the limiting factor affecting liveweight gains (Prachett et al 1977; Zimmerman 1980; McKay and Frandsen 1969; Ward 1975). In 
addition, the seasonal peak of protein availability for $A$. albida occurs in the mid to late dry season when most extensive pastoral production systems suffer severe protein deficiency (Miehe 1986).

Acacia albida has a number of characteristics which facilitate its integration into cropping systems, to the benefit of these systems. The most important of these is the tree's habit of shedding its leaves at the onset of the growing (wet) season, and leafing out during the dry season. Although this 'reverse phenology' is unusual, it is not unique to this species (Radwanski and Wickens 1967). Thus forage is available when livestock need it most, and is not on the tree when it would interfere with crop production (Radwanski and Wickens 1967; Miehe 1986; Poschen 1986; Houerou 1980a; Leach and Mearns 1988).

\section{Acacia albida and Crop Cultivation}

The positive influence of $A$. albida on crop yields is becoming widely known (Radwanski and Wickens 1967; Miehe 1986; Poschen 1986; Houerou 1980a). In many cases the increase in yield constitutes the most important single benefit of integrating acacia onto crop lands (Poschen 1986). Reported increases in yields in association with A. albida include 250\% for millet (Charreau and Vidal 1965), 100\% for sorghum (Poschen 1983), and as much as a six-fold increase for maize (Poschen 1986). Most of this increase can be attributed to: nitrogen fixation by the tree; the concentration of manure near trees (Leach and Mearns 1988); leaves entering the soil (Houerou (1980a); and improvements in soil structure, microclimate, and water drainage (Jung 1967; Dancette and Poulain 1965; Radwanski and Wickens 1967; Poschen 1986). Organic matter in the upper layers of the soil column has been found to be twice as high under acacia as that of open ground (Houerou 1980a). Felker (1978) has estimated that the addition of acacia on rainfed farms could increase the human carrying capacity from 10-20 to 40-50 people/ $\mathrm{km}^{2}$.

\section{Study Area}

Fieldwork was conducted just prior to the current famine in Somalia. While much of the land use description of the study area presented here may now be altered, it is relevant to many situations in semi-arid Africa, as well as to the future of Somalia. 


\section{Setting}

The study site was located in southern Somalia, in the lower Shabelle flood plain, approximately $100 \mathrm{~km}$ south of the capital, Mogadishu, and $11 \mathrm{~km}$ inland from the coastal city of Merca (Figure 1). The site is situated between $44030^{\prime}$ and 450 east longitude, and 1030 ' and 20 degrees north latitude. The area is characterized by fairly level topography, fine textured soils, and a tropical semiarid climate (TAMS 1986). Located adjacent to the shabelle river, the site covers approximately 8,500 variably irrigated hectares. It is bordered by coastal sand dunes to the east and south and an old river channel to the north and west (Figure 1).

\section{Environment}

Average annual precipitation for the study area is $400 \mathrm{~mm} /$ year, ranging from 282.3 to $736.0 \mathrm{~mm} /$ year (Ministry of Agriculture Meteorological Service 1988). Precipitation is distributed in a bimodal pattern with two alternate wet and dry seasons. The Gu season is the major rainy season lasting from April to June, followed by the minor Hagai dry season (July september). The Der season follows the Hagai and is a minor rainy season lasting from october to December, followed by the major Jilaal dry season from January through March. Characteristics of the rainfall pattern in southern somalia include scarcity, poor distribution, variability in the onset of the wet season and high variability in the amount of precipitation from year to year. This results in a drought recurrence interval of every four to five years (Handulle and Gay 1987) .

The soils of the project area are primarily vertisols. Textures are very heavy with up to 85\% clay, a high proportion of which are expanding clays (TAMS, 1986). The fineness of the soil pores causes soil moisture to be held in high tensions, with relatively little available to plants without irrigation (TAMS, 1986).

Species of acacia are presently found in the gallery forests of the Shabelle and Jubba rivers and in the interriverine bushland (Douthwaite 1985; LRDC 1985).

\section{Land Use}

The study area is part of a larger irrigation complex (Figure 1) put into operation by Italian colonists in the $1920 \mathrm{~s}$ and 1930s. The owners of the Italian plantations or "aziendas" (represented by rectangles of varying size in Figure 
1) departed in the 1960s, and smallholder subsistence irrigated agriculture has since become the dominant form of cultivation in the area for much of the past 30 years. In order to facilitate irrigation, the small farmers organized themselves into groups, made up of farmers cultivating land within the boundaries of the old Italian aziendas, and governed by 'azienda committees' comprised of the small farmers themselves. The population of the small farmer area was 3.3 people/ha. Average farm size-several parcels comprised one farm--was 2.24 ha.

Within the study area there were four separate land use interests, each with very specific and often conflicting agricultural arrangements, goals, and agendas. Those engaged in plantation agriculture usually had the backing of the national government and were engaged in the production of cash crops such as bananas for export. Large farmers not growing export crops were engaged in the production of much needed food for the rapidly expanding urban centers. Both the large farmer and plantation areas were located along the river and large canals (Figure 2) where access to water is relatively secure. The small, or subsistence farmers were the most populous group (comprising about $60 \%$ of the study area) and sought to provide for themselves and grow occasional surpluses to be sold in local or urban markets. The small holder areas were located further away from the river (Figure 2) and were more variably irrigated. Meaning that a percentage of farms were often cultivated under rainfed conditions or with less than optimal irrigation. Nomadic pastoralists had access to the small farm areas in the dry season subject to a number of constraints, and were primarily interested in getting through the dry season and occasional droughts with as little loss to their herds as possible.

\section{Pastoral Systems}

Up until the current famine, approximately 80\% of the Somali population participated in livestock production of some kind, while 55\% of the population was directly engaged in nomadic pastoralism (Bennett 1984; Lewis 1975; Box 1968 1971; Biswas et al 1987; Conze and Labahn 1986).

The pastoral systems of Somalia are made up of cattle, camels, sheep, and goats. Nomadic herds are found in the Lower Shabelle region from the end of the Hagai dry season to the end of the Jilaal dry season, until the Gu rains began. Herds spend the Jilaal concentrated on croplands in proximity to the river where they feed primarily on crop residues. As the dry season 
progresses livestock concentrations increase, and in severe droughts pastoralists and their livestock are drawn from other areas to compete for forage resources (RMR 1984). Dry season livestock migrations into the shabelle river basin just inland from Merca (which includes the study site) results in one of the highest livestock densities in the country (RMR 1984).

As agriculture and development schemes expanded along the river the flood retreat pastures which served as dry season forage areas for nomadic herds were greatly reduced (LRDC 1985; Conze and Labahn 1986; TAMS 1986). This made the problem of locating dry season grazing increasingly difficult. Although land degradation in the interior was pronounced in recent decades as a result of year-long grazing and improper land use (Biswas et al 1987; Box 1968 1971), the present famine and associated refugee activities have most likely decreased further the productive capacity of this resource.

\section{Surveys and Area Measurements}

\section{Data Acquisition}

The data for this analysis were collected from 1987 to 1989, and involved questionnaire surveys, field, farm, and area boundary measurements, and key informant interviews.

Three separate groups were the subject of formal

questionnaire surveys: agropastoralists, small farmers (less than $25 \mathrm{ha}$ ), and large farmers (25 ha and above). The agropastoralist survey was made up of 123 nonrandomly selected interviews, and focused on livestock carrying capacity issues. The small farmer survey involved three rounds of questionnaires given to 114 randomly selected participants, and dealt with a number of topics in depth in order to reveal the details of inplace land use practices. The large farmer survey comprised 30 nonrandomly selected participants who were interviewed once and were asked much of the same information as the small farmers.

\section{Elements of Acacia Fodder Production Trees on boundaries}

The total boundary distance in the study area with the potential to be planted in fodder trees was calculated for large canals (primary and secondary canals), roads, aziendas, and small farmer areas (Figure 2). This was done using distance measurements from the field, and a map of the irrigated area; from which Figure 2 is a much simplified rendition. For large canals and roads, double rows of trees are possible (one row on each side of the canal or road). For azienda and farm 
boundaries only a single row of trees is feasible. Available farm boundaries were calculated using the average size for small farms obtained from parcel measurements. Only one side of each farm (envisioned as a square) was included in the distance summation for available boundary. This was to avoid possible double accounting of available distance due to farmers from adjacent farms electing to plant trees on a shared boundary. However this conservative approach to available farm boundary results in an underestimate of available farm boundary by as much as 50\%. Such an underestimate would also allow for many farmers to plant no trees at all.

The densest spacing of trees along these boundaries was estimated using the average canopy area of a mature Acacia albida tree $\left(155 \mathrm{~m}^{2}\right)$ following (Poschen 1986). Thus the distance from the center of the tree to the edge of the canopy is half of the square root of $155 / 3.14$, or $3.5 \mathrm{~m}$. This is then added to the same distance from the neighboring tree, to give a total between tree (trunk) spacing of $7 \mathrm{~m}$. However trees cannot always be planted with the closest possible spacing. For various reasons it may not be possible for the densest spacing of trees to occur uniformly over the entire study area. Thus for this analysis, tree spacing is considered at 7, 14, and 21 m.

\section{Fodder production from Acacia albida}

While both the leaves and seed pods from $A$. albida are frequently used for livestock fodder, this study considers livestock carrying capacity from the pods alone. This is because for $A$. albida pods provide the highest quality fodder, and the entire seasonal pod production from a stand of trees can potentially be consumed. For acacia foliage, proper management of tree pruning is very important. However in many cases, the maximum yearly sustainable quantity which could be harvested is not known with much certainty. Thus leaves from A. albida could be seen as a fodder reserve in times of drought when greater than normal numbers of livestock would arrive earlier and stay longer in the irrigated area.

Dry matter (DM) pod production per tree can vary depending on a variety of localized factors, including soil: elevation, climatic regime, spacing, insect damage, and management practices. Radwanski and Wickens (1967) report a pod production of $135 \mathrm{~kg} / \mathrm{yr}$ in Jebel Marra, Sudan. Boudet and Toutain (1980) note production of over $100 \mathrm{~kg} / \mathrm{yr}$ for the subhumid SaheloSudanian zone. Most estimates however are somewhat lower. 
Houerou (1980a) estimates a production of 20 to $30 \mathrm{~kg} / \mathrm{ha}$ for arid and semi-arid savannas. And Miehe (1986) estimates a production of from 20 to $50 \mathrm{~kg} / \mathrm{yr}$ again for Jebel Marra, but notes that most estimates of pod production range between 10 and $75 \mathrm{~kg} / \mathrm{yr}$. In order to encompass these variations, pod production is considered here at 30, 50, 75, and $100 \mathrm{~kg} / \mathrm{yr}$.

\section{Feed value of Acacia albida pods}

The "feed value" of forage plants is defined as that portion of a unit of fodder which contributes directly to livestock maintenance (Houerou 1980a). This fraction can vary considerably between forage species, and has a direct influence on stocking rates (Houerou 1980a). Feed value is usually stated in fodder units (FU) and is expressed as a decimal fraction of a kilogram of dry matter. For fodder producing trees feed value varies with the parts of the plant consumed, the phenological stage of the plant or plant parts when consumed, selectivity by livestock, ingestability, digestibility, and to some degree the type, age, physiological condition, and feeding habits of livestock utilizing the resource (Houerou 1980b). For A. albida Houerou (1980a) gives a feed value of 0.85-0.95 FU/kg DM. For the purposes of this study an average value (0.90) is used in calculations of carrying capacity.

\section{Seedling survivability}

Acacia albida can experience high variability in the survival of seedlings. The species is quite sensitive to seedling production and outplanting mistakes and slight mistakes in timing of planting can reduce survival rates significantly (Poschen 1986). However if proper care is taken conventional methods can result in high survival rates (Poschen 1986).

Poschen (1986) discusses some of the relevant variables involved in acacia seedling survival. A field trial in Ethiopia demonstrated 50-90\% survival nine months after planting, and 75\% after two years (Poschen 1983). For the purposes of this investigation survival rates of 60,80 , and $100 \%$ are examined.

\section{Standard stock units (SSU)}

For Somali specific breeds, herd age structure, feeding habits, and liveweights Field (1980) calculates a Somali standard stock unit (SSU) to be a mature bovine with a liveweight of $450 \mathrm{~kg}$ that consumes $4,100 \mathrm{~kg}$ of dry matter per year. In this framework one SSU is equivalent to two camels or cattle, 20 sheep or goats, or 5 donkeys. 


\section{Livestock dry matter intake}

Maintenance consumption of dry matter for cattle as the major reference animal is usually put at 2.5\% of body weight per day (Jahnke 1982). For one SSU of $450 \mathrm{~kg}$ this is equivalent to $11.23 \mathrm{~kg}$ of $\mathrm{DM} / \mathrm{day}$ or $1011 \mathrm{~kg}$ for a three month dry season; the value used in this study. Whether this is sufficient for maintenance and production depends on a number of factors, including: energy content of forage consumed, digestibility, content of digestible protein, the amount of essential elements and nutrients, and the availability of water; as well as livestock disease, stress (climate, travelling distances) and husbandry methods (Jahnke 1982). The definition of maintenance can vary as well. Ideally maintenance would mean continuation of optimal animal weight and metabolism. However given the actual context of pastoralism in much of Africa, maintenance can often mean little more than survival of livestock through the current dry season, drought, or famine. In such a situation a considerable reduction in weight and optimal metabolic functioning would occur following consumption of less than the above mentioned standard, and the livestock concerned would still be "maintained". Under these circumstances, calculations of carrying capacity using this standard would be an overestimate, thus erring on the conservative side.

\section{SSU Carrying Capacity}

The variability which exists within the above mentioned elements, in addition to the frequency of good, average, and poor water years, govern the character and magnitude of livestock carrying capacity. These, with the exception of water years, have been included in calculations of carrying capacity for the study area using the equation below. The variation in water availability is considered later.

\section{Equation 1 .}

$\mathrm{K}=[[\mathrm{Ri}(\mathrm{Db} / \mathrm{Sm})](\mathrm{Tp} * 0.9)] / 1011] / 8500$

Where:

$\mathrm{K}=$ Carrying capacity in SSU/ha;

$\mathrm{Ri}=$ Rate of survival of seedlings, where $i=60,80$, or $100 \%$;

$\mathrm{Db}=$ Distance of boundary to be planted in fodder trees, where boundary $(\mathrm{b})=$ all boundaries $(562.94 \mathrm{~km})$, canals and roads $(139.05 \mathrm{~km})$, aziendas $(83.75 \mathrm{~km})$, and farms at: 30\% (102.23 $\mathrm{km})$, $50 \%(170.38 \mathrm{~km})$, and $100 \%(340.76)$; 
$\mathrm{Sm}=$ Spacing of trees in meters, where $\mathrm{m}=7,14$, or 21 meters; $\mathrm{Tp}=$ Tree pod production (kg/yr), where $\mathrm{p}=30,50,75$, or $100 \mathrm{~kg}$;

0.9 = The decimal fraction of one $\mathrm{kg}$ of $\mathrm{DM}$ fodder production, for

Acacia albida;

1011 = The optimal quantity (kg) of DM needed for maintenance of one SSU for a three month dry season;

8500 = Total hectares in the study area.

Thus the production of fodder (pods) per tree (Tp) is multiplied by the feed value (0.9) for $A$. albida to give the usable fodder (in $\mathrm{kg}$ ) per tree for livestock. This is then multiplied by the number of trees on-scheme, which is obtained by dividing the total boundary distance planted in trees (Db) by the average tree spacing along the boundaries (Sm), multiplied by the survivability of acacia tree seedlings (Ri). This total $\mathrm{kg}$ of available DM from acacia pods is then divided by the amount of fodder of DM needed to maintain one SSU for three months $(1011 \mathrm{~kg})$, to get the total number of SSU potentially maintained in the entire study area for three months. This is then divided by the 8500 ha scheme size to obtain the per hectare SSU carrying capacity (K). Table 1 summarizes the interplay among the terms of the equation which determine carrying capacity given the variation in these terms.

\section{Influence of Constituent Elements on Carrying Capacity}

\section{Biophysical Variables}

Table 1 allows comparison between livestock carrying capacities, permitting examination of the magnitude of influence of the different elements. Horizontal comparison of values within a 'Tree spacing' column-block (ie., below the numbers 7, 14, and 21) allows comparison of the difference in per hectare SSU carrying capacity due to differences in survivability (60, 80, 100\%) for a given tree productivity, spacing, and boundary length. Vertical comparison of values within a block allows examination of productivity per tree $(30,50,75,100 \mathrm{~kg})$ for a given survivability, tree spacing, and boundary length. Horizontal comparison of a single value within one block to an analogous value in a neighboring block allows observation of the differences in carrying capacity due to tree spacing, for a given survivability, production, and boundary length. Vertical comparison of analogous values in different blocks provides a 
look at differences due to boundary length (ie., different boundary categories) for a given fodder production per tree, survivability, and tree spacing.

Some elements or influences will be stronger than others and some can be more easily managed than others. Exploring the relationships between strength and ease of modification of these elements would enable those that are modifiable to be managed in such a way as to offset influences from elements that are more difficult to change. This would allow for greater flexibility in engineering the carrying capacity necessary to connect the actual number of livestock that need to be sustained, with the production of fodder from acacia. For example, pod

productivity, and seedling survivability over the entire 8500 ha study site would be much harder to control, given the variables which comprise these, than would tree spacing along boundaries, or the total length of boundaries planted within the different boundary categories. However these latter elements would be subject to a number of constraints.

\section{Tenure and Institutional Capacity}

Although tree spacing, and total length of boundary planted are the easiest of the determinants of carrying capacity to control, planting trees along different categories of boundary would entail different degrees of effort, time and money, as the capacities of the different institutions which exercise tenure control over these boundaries become known. It may be much easier for example for an outside entity, a ministry of agriculture or development organization, to implement planting and maintenance of trees along large canals and roads, than it would to promote planting on aziendas or farms. This is because the state could exercise tenure control over canal and road boundaries, but not over the boundaries of aziendas and farms. Defacto tenure control over these latter two is in the hands of azienda committees (comprised of farmers), and individual small farmers, respectively; and is subject to their initiative and management.

However livestock carrying capacity from trees planted just along the large canals and roads may or may not be enough, depending on the quantity of livestock which needs to be sustained, tree spacing, pod productivity per tree, and seedling survivability. If not, decreased spacing between trees would increase carrying capacity, but at some point a limit will be reached due to a minimum spacing having been attained, or the limits of the institutional capacity and inclination to organize 
and fund tree planting and maintenance will be approached. In either case if the trees will not meet the carrying capacity requirements of the livestock which normally frequent the area, the azienda and/or farm boundaries may be considered. The approach with both of these however will be different. Here extension efforts and incentives will have varying degrees of success.

For the azienda boundaries these efforts will interact with the organizational capacities, and preferences of the azienda committees. Such capacities will vary with the azienda (large farmer azienda, small farmer azienda, and differences within these) to result in a percentage of all possible azienda controlled boundaries (from 0 to $100 \%$ ) being planted and maintained. Likewise extension efforts to promote planting and maintenance of acacia on farm boundaries will interact with a number of socio-economic issues operating at the individual level, as well as personal preference and initiative. This will result in a percentage of the total available farm boundary actually having trees. Table 1 attempts to embrace, in a coarse way, some of these percentages $(30,50,100 \%)$ and the resulting differences in livestock carrying capacity.

Thus the capacities of the three different institution types which exercise tenure control over the three boundary types, and the time, effort and money needed for incentives to engage and strengthen these capacities, must be taken into account in order to meet a needed livestock carrying capacity.

\section{Discussion}

\section{Comparison of Calculated and Required Carrying Capacity}

By knowing the livestock per hectare density in the study area that is not sustained by other means, the values in Table 1 could be used to gain insight into possible spacing and boundary options.

In the Jilaal dry season of a good water year 644.8 SSU cannot be sustained by the crop residues available in the study area (Unruh 1991). Divided by the number of hectares in the study area gives a per hectare needed carrying capacity of 0.08 SSU/ha. There are a number of individual values in Table 1 which are greater than 0.08. As well, combinations of numbers less than 0.08 can be located in separate boundary categories such that the sum would equal or exceed 0.08. For an average water year, when a decreased production of crop residue sustains less livestock, the number which cannot be sustained is increased to $1765.5 \mathrm{SSU}$, or $0.21 \mathrm{SSU} / \mathrm{ha}$ (Unruh 1991). For a 
poor water year, the number of SSU not sustained is 3762.3 , or 0.44 SSU/ha (Unruh 1991).

While the dry season of a poor water year is the most critical time, a poor year only occurs four years out of ten, an average year three years out of ten, and a good water year three years out of ten (Unruh 1991). If the objective were to sustain livestock in an average water year, the area would then be able to support nomadic herds six years out of ten (good plus average). Some stress in some years with respect to available dry season forage is perhaps desirable in order to maintain relatively constant livestock numbers in the long term. Even natural river basin grazing is not likely to sustain all livestock in all poor and drought water years. If all nomadic herds visiting the study site were sustained every poor water year, the result might be large increases in herd size, similar to what occurs during a series of good rainfall years.

For an average water year there are a number of places in Table 1 where something close to the needed 0.21 SSU/ha can be found. Because the small farmer area occupies $60.5 \%$ of the scheme, most opportunities to encounter something close to 0.21 lie within this area. However there are several options that would include the canals/roads and azienda categories as well. If, for example, pod production and seedling survivability are both high, then the value located in the lower right of the block at the $7 \mathrm{~m}$ spacing and canals/roads boundaries might be an option. If productivity is low but survivability high, combinations from other categories will be needed. One possibility is the value of 0.10 at $50 \mathrm{~kg} /$ tree productivity and $100 \%$ survivability in the $7 \mathrm{~m}$ spacing block for the canals/roads category, together with the value 0.06 at the same productivity, survivability and spacing in the aziendas category, and the value 0.06 at the same productivity and survivability in the 14 $\mathrm{m}$ spacing block for 50\% of the farm boundaries. These total to $0.22 \mathrm{sSU} / \mathrm{ha}$. Different combinations are also possible if both productivity and survivability are lower.

The point is that many combinations are possible within and among the three boundary categories for obtaining a desired SSU/ ha carrying capacity. Thus there can be a number of opportunities for offsetting or taking advantage of variations in survivability, and productivity, as well as institutional capacity.

While Table 1 demonstrates the interplay between the primary elements which make up carrying capacity in this case, a table and analysis of this sort could be improved greatly by 
increasing both the number of gradations within any single element, and in the number of elements. Gradations within any single element could be changed from discrete to continuous. The number of elements could be increased by considering the factors which make up the primary elements noted in the 'Data Acquisition' section above. Including these 'secondary elements' might increase the number of variables which could be controlled or managed. This might result in an increase in the precision of the predictive capacity of the analysis, and in the number of possible options. Thus the purpose of Table 1 here is only illustrative.

\section{Potential Problems \\ Tsetse}

The tsetse fly (Glossina spp.) poses severe constraints to livestock production in much of Africa (LRDC 1984 1985; Douthwaite 1985). Because tsetse habitat consists of tree and bush lands, and this study investigates planting trees on irrigated farmlands, some discussion is warranted.

In Somalia, the gallery forest along the river supports the highest densities of tsetse (Douthwaite 1985). As these and other natural woody areas along the shabelle river basin decrease with clearing for cultivation, so will the tsetse fly problem associated with this vegetation (Douthwaite 1985; LRDC 1985). How much of a decrease this might be, and its comparison to any increase brought on by planting acacia is unknown. Although the tsetse fly is a significant problem for livestock, starvation and not trypanosomiasis is most likely the main cause of livestock mortality in many farming areas of Somalia (Douthwaite 1985).

An important aspect of this problem is bush encroachment in the rangeland interior. Livestock excluded from, or not adequately sustained within traditional dry season grazing and watering locations are forced to overgraze interior rangelands, resulting in land degradation. While degradation of this type in many areas often results in loss of vegetation and soil cover, in southern Somalia the trend has been one of bush encroachment; facilitating the spread of tsetse (Douthwaite 1985). In the lower Shabelle valley (the region of the study) heavy grazing during the last several decades has resulted in the conversion of hundreds of square kilometers of savanna grassland into dense bushland (LRDC 1984). Under these circumstances, facilitating dry season livestock maintenance in traditional riverine areas would work against the trend of 
increasing tsetse habitat in the interior, where the herds spend most of the year.

Within the study site permanent tsetse habitat exists where dense bush vegetation has developed along irrigation canals and boundary bunds, harboring very high densities of the fly (LRDC 1985). Irrigation development itself can thus act to extend tsetse infestation (LRDC 1985). If these thickets are cleared however and planted instead with $A$. albida, this infestation may be reduced. This is because if trees planted along canals and other boundaries have an open understory, and the overstory is relatively high, and the ground surface clean weeded, then tsetse infestation is not likely (Rocheleau et al 1988). Poschen (1986) recommends, for optimal fodder and wood production, that pruning take place on $A$. albida so that the lowest branch of the tree is at a height of not less than four meters, which would allow for an open understory. Thus replacement of these thickets by acacia trees could result in an overall decrease in tsetse infestation in the immediate area.

\section{Growth of $A$. albida}

A separate potential problem is the long maturation time required for $A$. albida, especially in arid regions. While the study site in somalia is semi-arid, water is not likely to be a problem due to irrigation. And in many cases fairly rapid regeneration of trees can be encouraged by systematic management (Miehe 1986). In any case given the benefits which can be obtained from acacia, the associated time lag still allows utilization of the trees to compare favorably with other land use components (Poschen 1986).

\section{References}

Bennett, J.W., 1984. Political ecology and development projects affecting pastoralist peoples in east Africa. Land Tenure Center Research Paper No. 80, Land Tenure Center, Madison, WI. Biswas, A.K., Y.F.O. Masakhalia, L.A. OderoOgwel, and E.P. Pallangyo, 1987. Land use and farming systems in the Horn of Africa. Land Use Policy, 4: 419443.

Boudet, G.C., and B. Toutain, 1980. The integration of browse plants within pastoral and agropastoral systems in Africa. In: Le Houerou HN (ed.) Browse in Africa. Papers presented at the International Symposium on Browse in Africa, Addis Ababa, April 812 . 
Box, T.W., 1968. Range resources of Somalia. Journal of Range Management, 21: 388392 .

Box, T.W., 1971. Nomadism and land use change in Somalia. Economic Development and Cultural Change, 19: 222228.

Charreau, C., and P. Vidal, 1965. Influence de l'Acacia albida del. sur le sol, nutrition minerale et rendements des mils Pennisetum au Senegal. Agronomique Tropicale, 67: 626660.

Conze, P., and P. Labahn, 1986. Somalia: Agriculture in the Winds of Change. Saarbrucken, Germany: Schafbrucke Publishers.

Dancette, C., and J.F. Poulain, 1965. Influence of Acacia albida on pedoclimatic factors and crop yields. African Soils, 14: 143148 .

Douthwaite, R.J., 1985. Environmental aspects of tsetse fly eradication in Somalia. Final Report of the Environmental Biologist, National Tsetse and Trypanosomiasis Control Project. Tropical Development and Research Institute, Overseas Development Administration, Mogadishu.

Felker, P., 1978. State of the art: Acacia albida as a complementary permanent intercrop with annual crops. USAID, Washington, D.C.

Field, D.I., 1980. Grazing capacity of rangelands. Technical Note No. 2. Mogadishu, Somalia: Somali Range Bulletin 11.

Handulle, A.A., and C.W. Gay, 1987. Development and traditional development in Somalia. Nomadic Peoples, 24: 3643.

Houerou, Le H.N., 1980a. Agroforestry techniques for the conservation and improvement of soil fertility in arid and semi-arid zones. In: Houerou Le, LE (ed.) Browse in Africa. ILCA, Addis Ababa.

Houerou Le, H.N., 1980b. Planting and management methods for browse trees and shrubs. In: Houerou Le, LE (ed.) Browse in Africa. ILCA, Addis Ababa. 
Jahnke, H.E., 1982. Livestock Production Systems and Livestock Development in Tropical Africa. Postfach: Wissenschaftsverlag Vauk.

Jung, G., 1967. Influence de l'Acacia albida (Del.) sur la biologie des sols dirr. Dentre ORSTROM, Dakar, Senegal (Mimeo) .

Leach, G., R. Mearns, 1988. Beyond the Fuelwood Crisis. London: Earthscan Publications.

Lewis, I.M., 1975. Abaar: the Somali drought. International African Institute. Emergency Report 1, Oxford University Press.

LRDC (Land Resources Development Centre), 1984. Tsetse eradication and rangeland rehabilitation: conflict or harmony of interests? Land Resources Development Centre, Surbiton, England, (mimeo) .

LRDC (Land Resources Development Center), 1985. Land Use in TsetseAffected Areas of Southern Somalia. Surbiton, UK: Land Resource Development Center.

McKay, A.D., and P.E. Frandsen, 1969. Chemical and floristic components of the diet of zebu cattle (Bos indicus) in browse and grass range pastures in a semiarid upland area of Kenya. Tropical Agriculture, 46: 279292.

Miehe, S., 1986. Acacia albida and other multipurpose trees on the Fur farmlands in the Jebel Marra highlands, Western Darfur, Sudan. Agroforestry Systems, 4: 89119.

Ministry of Agriculture Meteorological Service, 1988. Precipitation. Ministry of Agriculture, Mogadishu, Somalia.

Poschen, P., 1986. An evaluation of the Acacia albidabased agroforestry practices in the Hararghe highlands of Eastern Ethiopia. Agroforestry Systems, 4: 129143.

Poschen, P., 1983. Status report on ongoing agroforestry research. Plant Science Department, Alemaya College of Agriculture, Ethiopia (mimeo) . 
Prachett, D., B.G. Capper, D.E. Light, M.D. Miller, A.S. Rutherford, T.W. Rennie, N.G. Buck, and J.C. Trail, 1977. Factors limiting livewieght gain of beef cattle on rangeland in Botswana. Journal of Range Management 30: 442445.

Radwanski, S.A., and G.E. Wickens, 1967. The ecology of Acacia albida on mantle soils in Zalingei, Jebel Marra, Sudan. Journal of Applied Ecology 4: 569579.

Raintree, J.B. (ed.), 1987. Land, Trees and Tenure. Nairobi: ICRAF and the Land Tenure Center.

Resource Management and Research (RMR), 1984. Somali Democratic Republic Southern Rangelands Survey. London: Resource Management and Research.

Rocheleau, D., F. Weber, and A. FieldJuma, 1988. Agroforestry in Dryland Africa. Nairobi, ICRAF.

TAMS (Tippetts Abbett McCarthy Stratton), 1986. Genale irrigation rehabilitation project: feasibility study. Annex I. Natural and Human Resources. Mogadishu, Somalia: Ministry of Agriculture.

Torres, F., 1983. Role of Woody Perennial in animal agroforestry. Agroforestry Systems, 1: 131163.

Unruh, J.D., 1991. Nomadic pastoralism and irrigated agriculture in Somalia: utilization of existing landuse patterns in designs for multiple access of 'high potential' areas of semiarid Africa. GeoJournal, 25:91108.

Ward, D.E., 1975. Seasonal weight changes of cattle on semidesert grassshrub ranges. Journal of Range Management, 28 : 7999.

Zimmerman, I., 1980. Factors influencing the feed intake and liveweight of beef cattle on a mixed tree savanna in the Tansvaal. Journal of Range Management, 33: 132136. 


\section{Figure Captions}

Figure 1. Location of the study site in Somalia and within the irrigated area (shaded).

Figure 2. The study site showing large canal, road, and azienda boundaries; and small farmer areas (white) and large farmer and plantation areas (shaded).

\section{Keywords}

Multiple land use, Pastoralism, irrigation, Acacia albida, Africa, Somalia 
Table 1. The relationship between important aspects of fodder trees within the study site in the context of livestock carrying capacity. The units are in SSU maintained per ha for three months. Farm boundaries are for small farms only.

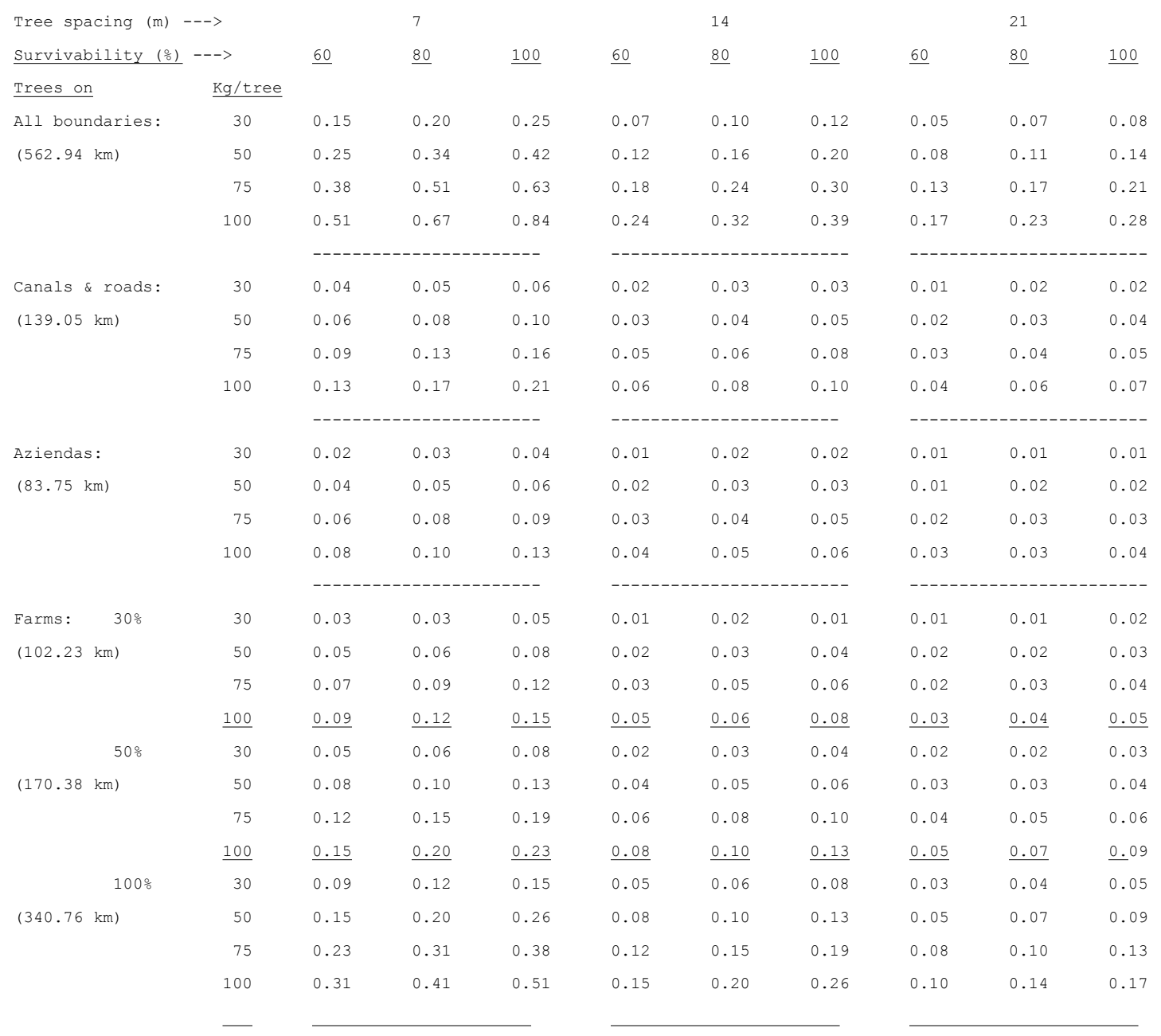

